\title{
Karakterisasi dan Evaluasi Keragaman Genotipe Semangka Lokal
}

\section{Characterization and Evaluation of Variability from Local Watermelon Genotype}

\author{
Abi Ardhillah Yasinda, Surjono Hadi Sutjahjo, Siti Marwiyah
}

Departemen Agronomi dan Hortikultura, Fakultas Pertanian, Institut Pertanian Bogor

(Bogor Agricultural University), Jalan Meranti, Kampus IPB Darmaga, Bogor 16680, Indonesia

Telp.\& Faks. 62-251-8629353 e-mail agronipb@indo.net.id

*Penulis Korespondensi : surjonohadisutjahjo@yahoo.co.id

Disetujui 7 Januari 2015/ Publish online 15 januari 2015

\begin{abstract}
Characterization is one of the first phases watermelon plant breeding activities. The process will trigger the appeareance of genetical diversity of the plants. The information regarding the genetical diversity of the observed characteristics is worthwhile the next phases of the breeding process. The experiment intends to achieve information of genetical diversity and directs for future research of the relations between the genetic relationship between watermelon genotype based on the level dissimilarities. The experiments has been implemented at the University Farm Leuwikopo, Bogor Agricultural University from October 2014 until January 2015. The experiment was arranged in a randomized complete block design with 8 genotypes of the exploration result and 1 genotipe for comparison. The diverse result of the analysis concludes that the test genotypes have certain effects to the observed characteristics. The characteristics of the weight of the fruit, length of the fruit, thickness of the pericarp, the total soluble solid of flesh, the day of flowering, and the harvest day have a high broad sense heritability predictive value. The character of the length of petiole have medium broad sense heritability predictive value, and the heritability predictive value of the fruit diameter character is not predictive. Based on the hedonic test, genotype Bengkulu 3 was the only preferred by the panelist due to its color, scents, texture, and the taste of the fruit characteristics. The result of cluster analysis conclude that genotypes originated from same origin generally will be grouped to the group of same genetic relationship.
\end{abstract}

Keywords: cluster, exploration, genetic relationship, hedonic, heritability

\begin{abstract}
ABSTRAK
Karakterisasi merupakan tahap awal dari kegiatan pemuliaan tanaman semangka. Berdasarkan kegiatan tersebut, akan diketahui keragaman genetik yang ada. Informasi mengenai keragaman genetik terhadap karakter yang diamati dapat dimanfaatkan pada tahap pemuliaan berikutnya. Percobaan ini bertujuan untuk memperoleh informasi keragaman genetik dan mempelajari hubungan kekerabatan antargenotipe semangka berdasarkan tingkat ketidakmiripannya. Percobaan dilaksanakan di Kebun Percobaan Leuwikopo, University Farm IPB pada Oktober 2014 hingga Januari 2015. Rancangan percobaan yang digunakan adalah rancangan kelompok lengkap teracak dengan 8 genotipe uji hasil eksplorasi dan 1 genotipe pembanding. Hasil analisis ragam menunjukkan bahwa pengaruh genotipe uji terdapat pada seluruh karakter yang diamati. Karakter bobot buah, panjang buah, tebal perikarp, kekerasan daging buah, padatan terlarut total daging buah, hari berbunga, dan hari panen memiliki nilai duga heritabilitas arti luar yang tinggi. Karakter panjang petiol memiliki nilai duga heritabilitas yang sedang, dan nilai duga heritabilitas pada karakter diameter buah tidak dapat diketahui. Berdasarkan hasil uji hedonik, hanya genotipe Bengkulu 3 yang disukai oleh panelis pada karakter warna, aroma, tekstur, dan rasa daging buah. Hasil analisis gerombol menunjukkan bahwa genotipe yang berasal dari daerah yang sama secara umum akan mengelompok pada kelompok kekerabatan yang sama.
\end{abstract}

Kata kunci : eksplorasi, gerombol, hedonik, heritabilitas, kekerabatan 


\section{PENDAHULUAN}

Salah satu komoditi hortikultura yang memiliki potensi untuk dikembangkan di Indonesia adalah semangka. Semangka (Citrullus lanatus (Thunb.) Matsum. \& Nakai) merupakan tanaman yang berasal dari daerah kering tropis dan subtropis Afrika. Semangka termasuk ke dalam keluarga Cucurbitaceae, satu keluarga dengan melon, mentimun, dan labu. Semangka merupakan tanaman semusim yang tumbuh merambat dengan panjang mencapai $5 \mathrm{~m}$ (Cahyono, 1996).

Produksi semangka secara relatif mengalami peningkatan pada kurun waktu 20102013, berturut-turut sebesar 348 631, 497 650, 515 505, dan 446913 ton (BPS, 2014). Peningkatan produksi dapat terjadi karena peningkatan permintaan dari konsumen. Peningkatan permintaan dipengaruhi oleh perubahan gaya hidup masyarakat yang mulai memperhatikan pemenuhan gizi, bertambahnya jumlah penduduk, dan peningkatan pendapatan.

Semangka diminati konsumen karena rasanya yang segar (Kalie, 1993). Semangka memiliki berbagai manfaat, diantaranya sebagai buah meja dan sebagai bahan untuk makanan olahan lain. Semangka mengandung zat antioksidan yang mampu menghidupkan aktivitas sel darah putih yang mampu meningkatkan kekebalan dan dapat membunuh sel-sel kanker (Prajnata, 2003).

Tanaman semangka bersifat menjalar dan memiliki alat pemegang seperti pilin. Permukaan tanaman (batang dan daunnya) tertutup bulu-bulu halus dan tajam (Sunarjono, 2004). Batang semangka berbentuk bulat dan lunak, berambut, dan sedikit berkayu dengan panjang antara 1.5$5.0 \mathrm{~m}$. Cabang-cabang lateral mirip dengan cabang utama. Daunnya berbentuk caping, bertangkai panjang, dan letaknya bersebrangan (Kalie, 1993). Rukmana (1994) menyatakan bahwa curah hujan yang baik bagi pertanaman semangka adalah 40-50 mm per bulan, dan cocok ditanam di daerah dataran rendah hingga ketinggian $600 \mathrm{~m}$ dpl. Menurut Mohr (1986), pertumbuhan tanaman dan pembentukan buah didorong oleh suhu yang tinggi (di atas $20{ }^{\circ} \mathrm{C}$ ) dan sinar matahari yang penuh.

Tanaman semangka termasuk ke dalam tanaman menyerbuk silang. Varietas tanaman ini terdiri dari dua jenis, yaitu hibrida dan nonhibrida. Petani relatif lebih menyukai menanam varietas hibrida karena varietas hibrida dapat menghasilkan tanaman dengan pertumbuhan yang kuat, produktivitas tinggi, seragam, dan tahan terhadap penyakit. Sampai saat ini benih semangka hibrida yang digunakan oleh petani sebagian besar merupakan varietas yang berasal dari luar Indonesia. Oleh karena itu, jika dapat dihasilkan benih semangka hibrida lokal yang sesuai dengan harapan petani maupun konsumen dengan harga yang relatif terjangkau, maka ketergantungan petani terhadap benih varietas luar Indonesia akan dapat dikurangi.

Perakitan varietas semangka harus didukung oleh keragaman genetik plasma nutfah yang tinggi. Keragaman genetik salah satunya dapat ditingkatkan dengan melakukan eksplorasi. Eksplorasi merupakan kegiatan pencarian bahanbahan genetik tanaman, berupa genotipe, kultivar, klon tanaman, baik dari alam, petani, atau kebun koleksi. Tujuan suatu eksplorasi ialah untuk memperkaya keragaman genetik koleksi plasma nutfah yang sudah ada. Percobaan ini bertujuan untuk memperoleh informasi keragaman genetik dan mempelajari hubungan kekerabatan antargenotipe semangka berdasarkan tingkat ketidakmiripannya.

\section{METODE PENELITIAN}

Percobaan dilaksanakan di Kebun Percobaan Leuwikopo, Laboratorium Pemuliaan Tanaman, dan Laboratorium Pascapanen Institut Pertanian Bogor pada bulan Oktober 2014 Januari 2015. Lokasi ini terletak pada ketinggian sekitar $201 \mathrm{~m} \mathrm{dpl} \mathrm{(BMKG,} \mathrm{2015).} \mathrm{Bahan} \mathrm{tanaman}$ yang digunakan dalam percobaan ini adalah 9 genotipe semangka yang terdiri atas 8 genotipe semangka lokal hasil eksplorasi yaitu Kefaminano 1, kefaminano 2, Kefaminano 3, Kefaminano 4, Bengkulu 1, Bengkulu 2, Bengkulu 3, dan Bengkulu 4, serta 1 varietas komersial sebagai genotipe pembanding yaitu Sugar Baby. Peralatan yang digunakan adalah tray, polybag, alat pengamatan di lapang (jangka sorong, penggaris), alat ekstraksi (saringan, wadah benih, sendok, pisau, kertas label), alat pengamatan pascapanen (timbangan digital, hand refractometer), dan sarana produksi tanaman.

Percobaan menggunakan rancangan kelompok lengkap teracak (RKLT) faktor tunggal yaitu genotipe semangka yang diulang sebanyak 3 kali, sehingga terdapat 27 satuan percobaan. Setiap satuan percobaan terdiri dari 10 tanaman, sehingga populasi tanaman sebanyak 270 tanaman.

Persemaian benih dilakukan pada tray yang telah diisi tanah, pupuk kandang, dan arang sekam dengan perbandingan 1:1:1 (v/v). Bibit dipelihara selama \pm 14 hari sampai daun kotiledon keluar sempurna. Lahan diolah dan dibuat bedeng 
setinggi 20-30 cm. Pemberian pupuk kandang dan kapur pertanian dilakukan dengan dosis masingmasing 15-20 ton ha ${ }^{-1}$ dan 2 ton ha ${ }^{-1}$.

Dosis pupuk SP-36 dan $\mathrm{KCl}$ yang digunakan adalah masing-masing $250 \mathrm{~kg} \mathrm{ha}^{-1}$ dan $375 \mathrm{~kg} \mathrm{ha}^{-1}$. Pasir halus dicampurkan secara merata ke bedeng dengan perbandingan antara tanah dan pasir sebesar 2:1 (v/v). Mulsa yang digunakan berupa plastik hitam perak dengan lebar $120 \mathrm{~cm}$. Sisi plastik yang berwarna perak menghadap ke langit.

Jarak tanam yang digunakan adalah $30 \mathrm{~cm}$ x $150 \mathrm{~cm}$. Bibit berumur 14 hari ditanam dalam bedeng dengan satu bibit per lubang tanam. Penanaman teratur sesuai dengan lay out percobaan. Pemberian insektisida dengan bahan aktif karbofuran 3\% dilakukan saat tanam dengan menebarkannya pada permukaan tanah di sekitar bibit yang ditanam. Pemupukan susulan berupa NPK 16:16:16 dilakukan sebanyak empat kali, yaitu ketika tanaman berumur 7, 14, 21, 28 HST dengan dosis masing-masing 5, 10, 20, $20 \mathrm{~g} \mathrm{~L}^{-1}$, diaplikasikan sebanyak $200 \mathrm{ml}$ per tanaman.

Pengamatan dilakukan dengan

karakterisasi morfologi tanaman yang mengacu pada deskriptor berdasarkan Pusat Perlindungan Varietas Tanaman (PPVT, 2007). Pengamatan dilakukan terhadap peubah kualitatif dan kuantitatif. Karakter kualitatif meliputi rasio helai daun, warna daun, intensitas warna daun, derajat cuping utama daun, derajat cuping kedua daun, bentuk penampang membujur buah, warna utama kulit buah, intensitas warna utama kulit buah, depresi pada pangkal buah, bentuk bagian apikal buah, depresi pada ujung buah, garis buah, tipe garis buah, intensitas warna garis buah, lebar garis buah, warna utama daging buah, intensitas warna utama daging buah, ukuran biji, warna dasar testa, warna sekunder testa, dan bercak pada hilum. Karakter kuantitatif meliputi panjang petiol, ketebalan perikarp, kekerasan daging buah, hari berbunga, hari panen, bobot buah, diameter buah, panjang buah, dan padatan terlarut total daging buah. Pengamatan tingkat kesukaan konsumen terhadap buah dilakukan dengan memberikan kuesioner pada 20 panelis tidak terlatih untuk mengetahui tingkat kesukaan dan penerimaan konsumen. Karakter yang diujikan adalah warna daging buah, aroma daging buah, tekstur daging buah, dan rasa daging buah.

Data yang telah didapatkan dianalisis dengan menggunakan uji $\mathrm{F}$. Jika terdapat pengaruh genotipe yang nyata, dilakukan uji perbandingan nilai tengah dengan metode Duncan's Multiple Range Test pada taraf 5\%. Hasil penilaian panelis pada uji kesukaan (hedonik) diuji menggunakan uji Friedman (Poste et al., 1991). Pendugaan ragam lingkungan, ragam genetik, dan ragam fenotipe dihitung berdasarkan nilai harapan kuadrat tengah masing-masing parameter. Analisis koefisien korelasi Pearson berdasarkan Walpole (1982). Koefisien keragaman genetik (KKG) dan koefisien keragaman fenotipe (KKF) dihitung berdasarkan rumus Singh dan Chaudary (1979). Pendugaan nilai heritabilitas arti luas (h2bs) dilakukan berdasarkan Allard (1960). Setelah itu dilakukan pengelompokan genotipe-genotipe berdasarkan tingkat ketidakmiripan fenotipiknya dengan menggunakan analisis gerombol. Metode analisis gerombol yang digunakan adalah Gower dengan metode pengelompokan Ward. Perangkat lunak yang digunakan antara lain Microsoft Excel 2007 (rekapitulasi data, pendugaan KKG, KKF, dan heritabilitas), SAS 9.1 (uji F, uji DMRT, dan pendugaan ragam, analisis koefisien korelasi), serta R i386 3.1.1 untuk melakukan analisis gerombol.

\section{HASIL DAN PEMBAHASAN}

\section{Kondisi Umum Percobaan}

Menurut data BMKG (2015), suhu ratarata per bulan pada lokasi percobaan adalah 26.15 ${ }^{0} \mathrm{C}$ dengan kelembapan nisbi rata-rata bulan-1 sebesar 70\%. Rata-rata curah hujan selama periode percobaan (Oktober 2014-Januari 2015) di lokasi percobaan adalah $328.5 \mathrm{~mm}$, sementara curah hujan yang dibutuhkan oleh semangka agar dapat tumbuh dan berkembang secara optimal hanya sebesar 40-50 mm (Rukmana, 1994).

Buah yang dihasilkan kurang manis karena curah hujan yang tinggi disertai panas yang berlangsung terus-menerus selama penelitian sehingga sangat memengaruhi kuantitas dan kualitas hasil panen (Rukmana, 1994). Kondisi pertanaman selama percobaan teridentifikasi mengalami serangan hama dan penyakit sehingga dilakukan pengendalian secara manual dan kimiawi. Hama yang diketahui menyerang pertanaman semangka selama percobaan adalah belalang (Oxya sp.) dan ulat tanah (Agrotis ipsilon) yang dikendalikan dengan insektisida berbahan aktif karbofuran dan profenofos. Penyakit yang ditemui di lapang adalah WMV (Watermelon Mosaic Virus) dengan gejala tanaman menjadi kerdil, daun menjadi keriting, serta bercak berwarna kuning yang tidak teratur, dan busuk buah yang disebabkan oleh cendawan Phytopthora nicotianae. Penyakit busuk buah dikendalikan dengan mengaplikasikan fungisida 
berbahan aktif propamokarb hidroklorida dan propinep. Penyakit ini menyebabkan banyak buah muda yang busuk di lapang sehingga tidak dapat dipanen. Penyakit WMV dikendalikan dengan pencabutan dan pembakaran tanaman. Pascapanen semangka juga diserang oleh penyakit antraknosa yang disebabkan oleh cendawan Colletotricum langenarium (Pass) Ell. Est Halst. Identifikasi hama dan penyakit berdasarkan gejala dan tanda yang terlihat.

\section{Keragaan Agronomi Genotipe Semangka}

Hasil rekapitulasi sidik ragam keragaan agronomi pada peubah genotipe semangka dapat dilihat pada Tabel 1 . Hasil analisis sidik ragam menunjukkan pengaruh kelompok tidak nyata pada seluruh karakter yang diamati. Adanya respon yang sama pada kelompok yang berbeda menunjukkan bahwa kondisi lingkungan pada lokasi percobaan secara relatif bersifat homogen. Faktor genotipe memberikan pengaruh yang sangat nyata pada seluruh karakter yang diamati yaitu bobot buah, panjang petiol, panjang buah, diameter buah, tebal perikarp, kekerasan daging buah, padatan terlarut total daging buah, hari berbunga, dan hari panen. Pengaruh genotipe yang sangat nyata pada seluruh karakter yang diamati membuktikan bahwa minimal terdapat satu pasang genotipe memiliki perbedaan keragaan sehingga analisis dapat dilanjutkan.

Tabel 1. Rekapitulasi sidik ragam pada karakter pengamatan genotipe semangka

\begin{tabular}{|c|c|c|c|c|}
\hline Karakter & Nilai tengah & KT kelompok & KT genotipe & $\mathrm{KK}(\%)$ \\
\hline Bobot buah (g) & 1370.51 & $2229075.35 \mathrm{tn}$ & $12887.37 * *$ & 25.82 \\
\hline Panjang petiol $(\mathrm{cm})$ & 6.17 & $2.40 \mathrm{tn}$ & $4.49 * *$ & 18.72 \\
\hline Panjang buah $(\mathrm{cm})$ & 14.23 & $7.96 \mathrm{tn}$ & $61.76 * *$ & 14.95 \\
\hline Diameter buah $(\mathrm{cm})$ & 38.22 & $28.89 \mathrm{tn}$ & $88.14 * *$ & 13.37 \\
\hline Tebal perikarp $(\mathrm{cm})$ & 0.88 & 0.01 tn & $0.21 * *$ & 15.84 \\
\hline Kekerasan daging buah $\left(\mathrm{mm} \mathrm{s}^{-1}\right)$ & 124.05 & $58.34 \mathrm{tn}$ & $4312.72 * *$ & 11.93 \\
\hline PTT daging buah ( ${ }^{0}$ brix $)$ & 7.97 & $0.90 \mathrm{tn}$ & $22.41 * *$ & 14.01 \\
\hline Hari berbunga (HST) & 28.15 & $0.22 \operatorname{tn}$ & $11.30 * *$ & 2.21 \\
\hline Hari panen (HST) & 87.12 & $0.05 \mathrm{tn}$ & $11.99 * *$ & 0.52 \\
\hline
\end{tabular}

**KT: kuadrat terngah; KK: koefisien keragaman; PTT: padatan terlarut total; HST: hari setelah transplanting; **berpengaruh nyata pada taraf $1 \%$; tntidak berpengaruh nyata pada taraf $5 \%$

Berdasarkan informasi yang disajikan pada Tabel 2, rataan bobot buah dengan nilai paling tinggi sebesar $2432 \mathrm{~g}$ dimiliki oleh genotipe Bengkulu 2 sedangkan rataan bobot buah dengan nilai paling rendah dimiliki oleh genotipe Sugar baby sebagai varietas pembanding yaitu sebesar 553 g. Genotipe Kefaminano 4, Bengkulu 2, Bengkulu 3, dan Bengkulu 4 memiliki rata-rata bobot buah yang lebih tinggi dibandingkan rataan umum. Nilai tengah panjang buah tertinggi dimiliki oleh genotipe Bengkulu 3 yaitu sebesar $17.77 \mathrm{~cm}$ dan nilai tengah panjang buah terendah yaitu $10.39 \mathrm{~cm}$ dimiliki oleh genotipe Sugar Baby. Genotipe Kefaminano 4, Bengkulu 1, Bengkulu 3, dan Bengkulu 4 memiliki rata-rata panjang buah yang lebih tinggi dibandingkan rataan umum. Genotipe Kefaminano 4 memiliki rata-rata diameter buah paling tinggi yaitu $43.6 \mathrm{~cm}$ dan genotipe Sugar Baby memiliki rata-rata diameter buah paling rendah yaitu sebesar $32.65 \mathrm{~cm}$. Genotipe Kefaminano 1, Kefaminano 2, Kefaminano 4, Bengkulu 2, dan Bengkulu 4 memiliki rata-rata diameter buah yang lebih tinggi dibandingkan rataan umum.

Tabel 2. Nilai tengah karakter bobot buah, panjang buah, dan diameter buah genotipe semangka yang diujikan

\begin{tabular}{lccc}
\hline \multicolumn{1}{c}{ Genotipe } & Bobot buah $^{-1}(\mathrm{~g})$ & Panjang buah $(\mathrm{cm})$ & Diameter buah $(\mathrm{cm})$ \\
\hline Kefaminano 1 & $1225.20 \mathrm{~cd}$ & $10.91 \mathrm{~d}$ & $40.27 \mathrm{ab}$ \\
Kefaminano 2 & $1327.30 \mathrm{cc}$ & $11.63 \mathrm{~d}$ & $40.68 \mathrm{ab}$ \\
Kefaminano 3 & $887.60 \mathrm{de}$ & $13.78 \mathrm{c}$ & $36.26 \mathrm{bc}$ \\
Kefaminano 4 & $1877.20 \mathrm{~b}$ & $14.83 \mathrm{bc}$ & $43.60 \mathrm{a}$ \\
Bengkulu 1 & $1200.90 \mathrm{~cd}$ & $15.66 \mathrm{abc}$ & $35.89 \mathrm{bc}$ \\
Bengkulu 2 & $2432.00 \mathrm{a}$ & $14.19 \mathrm{c}$ & $39.54 \mathrm{ab}$ \\
Bengkulu 3 & $1512.50 \mathrm{bc}$ & $17.77 \mathrm{a}$ & $37.26 \mathrm{bc}$ \\
Bengkulu 4 & $1532.80 \mathrm{bc}$ & $16.83 \mathrm{ab}$ & $40.04 \mathrm{ab}$ \\
Sugar Baby & $553.10 \mathrm{e}$ & $10.39 \mathrm{~d}$ & $32.65 \mathrm{c}$ \\
\hline Rataan umum & 1370.51 & 14.23 & 38.22 \\
\hline
\end{tabular}

**Nilai yang diikuti dengan huruf yang sama pada kolom yang sama menunjukkan hasil yang tidak berbeda nyata secara statistik pada uji DMRT 5\% 
Tabel 3 menunjukkan bahwa rataan panjang petiol dengan nilai paling tinggi sebesar $7.06 \mathrm{~cm}$ dimiliki oleh genotipe Bengkulu 4 sedangkan rataan panjang petiol dengan nilai paling rendah dimiliki oleh genotipe Sugar Baby sebagai varietas pembanding yaitu sebesar 4.96 cm. Genotipe Kefaminano 2, Kefaminano 4, Bengkulu 1, Bengkulu 2 dan Bengkulu 4 memiliki rata-rata panjang petiol yang lebih tinggi dibandingkan rataan umum.

Nilai tengah tebal perikarp tertinggi dimiliki oleh genotipe Kefaminano 2 yaitu sebesar $1.13 \mathrm{~cm}$ dan nilai tengah panjang buah terendah yaitu $0.68 \mathrm{~cm}$ dimiliki oleh genotipe Kefaminano 3. Genotipe Kefaminano 3, Bengkulu 1, Bengkulu 2, dan Bengkulu 4 memiliki rata-rata tebal perikarp yang lebih rendah dibandingkan rataan umum. Genotipe Kefaminano 4 memiliki rata-rata kekerasan daging buah paling tinggi yaitu 164.86 $\mathrm{mm} \mathrm{s}^{-1}$ dan genotipe Sugar Baby memiliki rerata kekerasan daging buah paling rendah yaitu sebesar $101.25 \mathrm{~mm} \mathrm{~s}^{-1}$. Genotipe Kefaminano 3, Bengkulu 1, Bengkulu 2, dan Bengkulu 3 memiliki rata-rata kekerasan daging buah yang lebih tinggi dibandingkan rataan umum.

Tabel 3. Nilai tengah dan hasil uji lanjut karakter panjang petiol, tebal perikarp, dan kekerasan daging buah pada genotipe semangka yang diujikan

\begin{tabular}{lccc}
\hline \multicolumn{1}{c}{ Genotipe } & Panjang petiol $(\mathrm{cm})$ & Tebal perikarp $(\mathrm{cm})$ & $\begin{array}{c}\text { Kekerasan daging buah } \\
\left(\mathrm{mm} \mathrm{s}^{-1}\right)\end{array}$ \\
\hline Kefaminano 1 & $6.14 \mathrm{ab}$ & $1.01 \mathrm{ab}$ & $108.00 \mathrm{c}$ \\
Kefaminano 2 & $6.68 \mathrm{a}$ & $1.13 \mathrm{a}$ & $103.00 \mathrm{c}$ \\
Kefaminano 3 & $5.80 \mathrm{ab}$ & $0.68 \mathrm{c}$ & $135.22 \mathrm{~b}$ \\
Kefaminano 4 & $6.71 \mathrm{a}$ & $1.11 \mathrm{a}$ & $102.29 \mathrm{c}$ \\
Bengkulu 1 & $6.64 \mathrm{a}$ & $0.79 \mathrm{c}$ & $152.67 \mathrm{a}$ \\
Bengkulu 2 & $6.94 \mathrm{a}$ & $0.72 \mathrm{c}$ & $164.86 \mathrm{a}$ \\
Bengkulu 3 & $5.29 \mathrm{~b}$ & $0.97 \mathrm{~b}$ & $131.83 \mathrm{~b}$ \\
Bengkulu 4 & $7.06 \mathrm{a}$ & $0.81 \mathrm{c}$ & $107.63 \mathrm{c}$ \\
Sugar Baby & $4.96 \mathrm{~b}$ & $0.78 \mathrm{c}$ & $101.25 \mathrm{c}$ \\
\hline Rataan umum & 6.17 & 0.88 & 124.05 \\
\hline Nilai yang diikuti dengan huruf yang sama pada kolom yang sama menunjukkan hasil yang tidak berbeda nyata secara statistik pada \\
uji DMRT 5\%
\end{tabular}

Genotipe Bengkulu 3 memiliki rata-rata padatan terlarut total paling tinggi yaitu $9.92{ }^{\circ}$ brix dan genotipe Kefaminano 1 memiliki rata-rata padatan terlarut total paling rendah yaitu sebesar $5.63{ }^{\circ}$ brix (Tabel 4). Genotipe Kefaminano 3 dan seluruh genotipe yang berasal dari daerah Bengkulu memiliki rata-rata padatan terlarut total daging buah yang lebih tinggi dibandingkan rataan umum. Nilai tengah hari berbunga tertinggi dimiliki oleh genotipe Kefaminano 2 dan Sugar baby yaitu selama 30.00 HST dan nilai tengah hari berbunga terendah yaitu 26.14 HST dimiliki oleh genotipe Kefaminano 4.

Tabel 4. Nilai tengah dan hasil uji lanjut karakter PTT daging buah, hari berbunga, dan hari panen pada genotipe semangka yang diujikan

\begin{tabular}{llll}
\hline \multicolumn{1}{c}{ Genotipe } & \multicolumn{1}{c}{ PTT daging buah $\left({ }^{0}\right.$ brix) } & Hari berbunga (HST) & Hari panen (HST) \\
\hline Kefaminano 1 & $5.63 \mathrm{e}$ & $27.33 \mathrm{c}$ & $86.00 \mathrm{~d}$ \\
Kefaminano 2 & $6.45 \mathrm{de}$ & $30.00 \mathrm{a}$ & $87.00 \mathrm{~b}$ \\
Kefaminano 3 & $8.71 \mathrm{ab}$ & $28.67 \mathrm{~b}$ & $86.00 \mathrm{~d}$ \\
Kefaminano 4 & $5.70 \mathrm{e}$ & $26.14 \mathrm{~d}$ & $87.00 \mathrm{~b}$ \\
Bengkulu 1 & $9.16 \mathrm{ab}$ & $28.00 \mathrm{~b}$ & $86.67 \mathrm{bc}$ \\
Bengkulu 2 & $9.57 \mathrm{a}$ & $27.29 \mathrm{c}$ & $86.29 \mathrm{~cd}$ \\
Bengkulu 3 & $9.92 \mathrm{a}$ & $28.00 \mathrm{~b}$ & $87.00 \mathrm{~b}$ \\
Bengkulu 4 & $8.08 \mathrm{bc}$ & $28.13 \mathrm{~b}$ & $89.00 \mathrm{a}$ \\
Sugar Baby & $7.18 \mathrm{~cd}$ & $30.00 \mathrm{a}$ & $89.38 \mathrm{a}$ \\
\hline Rataan umum & 7.97 & 28.15 & 87.12 \\
\hline
\end{tabular}

PTT: padatan terlarut total; HST: hari setelah transplanting; Nilai yang diikuti dengan huruf yang sama pada kolom yang sama menunjukkan hasil yang tidak berbeda nyata secara statistik pada uji DMRT 5\%

Genotipe Kefaminano 1, Kefaminano 4, dan seluruh genotipe yang berasal dari daerah Bengkulu memiliki rata-rata hari berbunga yang lebih cepat dibandingkan rataan umum. Rataan hari panen dengan nilai paling tinggi yaitu selama 89.38 HST dimiliki oleh genotipe Sugar baby sedangkan rataan hari panen dengan nilai paling rendah dimiliki oleh genotipe Kefaminano 1 dan 
Kefaminano 3 yaitu selama 86.00 HST. Seluruh genotipe selain genotipe Bengkulu 3 dan Sugar Baby memiliki rata-rata hari panen yang lebih cepat dibandingkan rataan umum.

Tabel 5. Pendugaan potensi hasil pada genotipe semangka yang diujikan

\begin{tabular}{lc}
\hline \multicolumn{1}{c}{ Genotipe } & $\begin{array}{c}\text { Potensi hasil } \\
\text { (ton ha }^{-1} \text { ) }\end{array}$ \\
\hline Kefamenano 1 & 8.82 \\
Kefamenano 2 & 9.56 \\
Kefamenano 3 & 6.39 \\
Kefamenano 4 & 13.52 \\
Bengkulu 1 & 8.65 \\
Bengkulu 2 & 17.51 \\
Bengkulu 3 & 10.89 \\
Bengkulu 4 & 11.04 \\
Sugar Baby & 3.98 \\
\hline Produktivitas nasional & 14.86 \\
(BPS, 2014) & \\
\hline
\end{tabular}

Berdasarkan data yang dikeluarkan oleh BPS (2014), buah semangka yang di produksi di Indonesia adalah 446913 ton dengan luas panen seluas 35339 ha, sehingga produktivitas nasional buah semangka sebesar 14.86 ton $\mathrm{ha}^{-1}$. Genotipe Bengkulu 2 memiliki potensi hasil yang lebih tinggi dari genotipe lainnya (Tabel 5). Potensi hasil paling rendah dimiliki oleh genotipe Sugar Baby yaitu 3.98 ton ha-1. Genotipe yang memiliki potensi hasil yang lebih tinggi dari produktivitas nasional hanya genotipe Bengkulu 2.

\section{Korelasi Antar Karakter Kuantitatif}

Program pemuliaan lebih sering menggunakan pendekatan secara tidak langsung untuk memperbaiki karakter produksi, yaitu dengan menyeleksi karakter-karakter yang terkait dengannya. Korelasi antara dua atau lebih karakter yang dimiliki akan memudahkan seleksi karena peningkatan suatu sifat akan diikuti oleh peningkatan atau penurunan sifat lain yang memiliki korelasi (Eckebil et al., 1977). Korelasi antarkarakter yang negatif akan mempersulit dalam memperoleh sifat yang diharapkan dan bila tidak ada korelasi antara sifat yang diharapkan maka seleksi menjadi tidak efektif dan efisien (Poespodarsono, 1988).

Tabel 6 menunjukkan bahwa kekerasan daging buah berkorelasi positif secara sangat nyata terhadap padatan terlarut total daging buah, bobot buah, dan panjang buah, serta berkorelasi negatif secara sangat nyata terhadap tebal perikarp dan hari panen. Panjang petiol tidak berkorelasi nyata terhadap seluruh karakter yang diamati. Padatan terlarut total daging buah memiliki korelasi positif yang sangat nyata terhadap panjang buah dan hari berbunga, serta secara nyata terhadap karakter tebal perikarp.

Karakter bobot buah memiliki korelasi positif yang sangat nyata terhadap karakter diameter buah dan panjang buah, korelasi positif secara nyata terhadap karakter tebal perikarp, serta berkorelasi negatif yang sangat nyata terhadap hari berbunga. Diameter buah memiliki korelasi positif yang sangat nyata terhadap panjang buah dan tebal perikarp, serta berkorelasi negatif yang sangat nyata terhadap karakter hari berbunga. Panjang buah memiliki korelasi negatif yang sangat nyata terhadap hari berbunga. Tebal perikarp tidak memiliki korelasi yang nyata terhadap hari berbunga dan hari panen. Hari berbunga memiliki korelasi positif yang sangat nyata terhadap karakter hari panen.

Berdasarkan korelasi karakter kuantitatif di atas, maka strategi pemuliaan yang berpeluang dapat digunakan untuk meningkatkan bobot buah adalah dengan cara menggunakan genotipegenotipe yang memiliki diameter buah dan panjang buah yang besar. Berbeda jika strategi pemuliaan ditujukan pada pengurangan ketebalan perikarp, maka genotipe yang digunakan adalah genotipe yang memiliki diameter buah yang tidak terlalu besar.

Menurut Falconer (1964), faktor genetik yang menyebabkan korelasi terutama karena adanya pleiotropi, yaitu suatu alel yang dapat mempengaruhi ekspresi beberapa karakter. Korelasi yang terjadi merupakan hasil akhir dari pengaruh semua gen yang bersegregasi atau semua faktor lingkungan yang beraneka ragam yang mengendalikan karakter-karakter yang berkorelasi. Jika gen-gen yang mengendalikan pasangan karakter-karakter yang berkorelasi tersebut meningkatkan keduanya, maka akan diperoleh korelasi positif, sedangkan jika berlawanan akan berkorelasi negatif. Demikian juga jika karakter-karakter yang berkorelasi dipengaruhi oleh faktor lingkungan yang sama, tetapi akibatnya terhadap lingkungan tersebut berlawanan, maka akan diperoleh korelasi negatif. Lingkungan berperan penting di dalam korelasi ini, dalam beberapa kasus, lingkungan mempengaruhi dua karakter dengan arah yang berlawanan. Faktor genetik dan lingkungan akan bersama-sama membentuk nilai korelasi fenotipik (Saleem et al., 2006). 
Tabel 6. Koefisien korelasi linear antarkarakter pada genotipe semangka yang diujikan

\begin{tabular}{lllllllll}
\hline & K & PP & PT & BB & DB & PB & TP & HB \\
\hline PP & 0.12 & & & & & & & \\
PT & $0.66^{* *}$ & -0.18 & & & & & & \\
BB & $0.30^{* *}$ & 0.18 & 0.22 & & & & \\
DB & -0.02 & 0.12 & -0.04 & $0.67^{* *}$ & & & \\
PB & $0.30^{* *}$ & 0.00 & $0.53^{* *}$ & $0.49^{* *}$ & $0.39^{* *}$ & & & \\
TP & $-0.44^{* *}$ & 0.03 & $-0.29^{*}$ & $0.23^{*}$ & $0.47^{* *}$ & 0.07 & & \\
HB & -0.16 & -0.16 & $0.01^{* *}$ & $-0.51^{* *}$ & $-0.33^{* *}$ & $-0.33^{* *}$ & -0.15 & \\
HP & $-0.40^{* *}$ & -0.10 & -0.05 & -0.18 & -0.04 & 0.04 & -0.07 & $0.32^{* *}$ \\
\hline
\end{tabular}

K: kekerasan daging buah; PP: panjang petiol; PT: padatan terlarut total; BB: bobot buah; DB: diameter buah; PB: panjang buah; TP: tebal perikarp; HB: hari berbunga; HP: hari panen; **berkorelasi nyata pada taraf $1 \%$; *berkorelasi nyata pada taraf $5 \%$

\section{Analisis Parameter Genetik}

Pengetahuan mengenai keragaman genetik merupakan modal dasar bagi pemuliaan tanaman dan genetika populasi dalam pengembangan dan perbaikan tanaman, terutama sebagai langkah awal dalam seleksi tanaman. Langkah ini penting terutama untuk membedakan individu dalam spesies serta identifikasi varietas secara tepat dan identifikasi gen-gen yang berpotensi membawa karakter unggul (Thormann et al., 1994).

Nilai koefisien keragaman fenotipe lebih besar dari koefisien keragaan genotipe pada seluruh karakter kuantitatif yang diamati (Tabel 7). Menurut Jalata et al. (2011), nilai KKF yang lebih besar dari KKG mengindikasikan bahwa seleksi dapat dilakukan berdasarkan keragaan karakter-karakter tersebut. Namun menurut Gupta dan Verma (2000), KKF yang lebih besar dari
KKG juga menunjukkan bahwa keragaman yang tampak pada karakter tersebut lebih banyak dipengaruhi oleh faktor lingkungan daripada faktor genotipe.

Nilai KKG yang mendekati atau hampir sama dengan KKF menunjukkan bahwa faktor lingkungan berpengaruh kecil terhadap keragaman yang terjadi pada karakter yang diujikan, sehingga seleksi dapat efektif dilakukan pada karakter tersebut berdasarkan keragaannya (Aditya et al., 2011).

Heritabilitas arti luas (h2bs) merupakan rasio antara ragam genetik total dengan ragam fenotipik (Allard, 1960). Heritabilitas merupakan bagian pengaruh genetik dari keragaan fenotipe yang dapat diwariskan dari tetua kepada turunannya (Kusdiarti, 1986). Nilai duga heritabilitas dikategorikan tinggi jika $\mathrm{h} 2>0.5$, sedang jika $0.2<\mathrm{h} 2<0.5$, dan rendah jika $\mathrm{h} 2<0.2$ (Stansfield, 1991).

Tabel 7. Nilai duga komponen ragam dan heritabilitas arti luas karakter kuantitatif dari genotipe semangka yang diujikan

\begin{tabular}{llllllll}
\hline Karakter & $\sigma 2 \mathrm{e}$ & $\sigma 2 \mathrm{~g}$ & $\sigma 2 \mathrm{f}$ & $\mathrm{KKG}$ & $\mathrm{KKF}$ & $\mathrm{h} 2 \mathrm{bs}$ & \\
\hline $\begin{array}{l}\text { Bobot buah } \\
\mathrm{g} \text { ) }\end{array}$ & 121379.00 & 280089.00 & 320548.67 & 38.62 & 41.31 & 87.38 & $\mathrm{~T}$ \\
$\begin{array}{l}\text { Panjang petiol } \\
\text { (cm) }\end{array}$ & 1.33 & 0.39 & 0.84 & 10.16 & 14.81 & 47.01 & $\mathrm{~S}$ \\
$\begin{array}{l}\text { Panjang buah } \\
(\mathrm{cm})\end{array}$ & 4.53 & 6.34 & 7.85 & 17.70 & 19.70 & 80.77 & $\mathrm{~T}$ \\
$\begin{array}{l}\text { Diameter buah } \\
(\mathrm{cm})\end{array}$ & 26.26 & 0.00 & 0.00 & 0.00 & 0.00 & 0.00 & \\
$\begin{array}{l}\text { Tebal perikarp } \\
\text { (cm) }\end{array}$ & 0.02 & 0.03 & 0.03 & 18.21 & 20.34 & 80.15 & $\mathrm{~T}$ \\
$\begin{array}{l}\text { Kekerasan } \\
\text { daging buah } \\
\text { (mm s-1) }\end{array}$ & 214.37 & 547.74 & 619.20 & 18.87 & 20.06 & 88.46 & $\mathrm{~T}$ \\
$\begin{array}{l}\text { PTT daging } \\
\text { buah (obrix) }\end{array}$ & 1.24 & 2.56 & 2.98 & 20.07 & 21.63 & 86.13 & $\mathrm{~T}$ \\
$\begin{array}{l}\text { Hari berbunga } \\
\text { (HST) }\end{array}$ & 0.38 & 1.51 & 1.64 & 4.37 & 4.55 & 92.25 & $\mathrm{~T}$ \\
$\begin{array}{l}\text { Hari panen } \\
\text { (HST) }\end{array}$ & 0.20 & 1.48 & 1.55 & 1.40 & 1.43 & 95.67 & $\mathrm{~T}$ \\
\hline T: tinggi, S: sedang; PTT: padatan terlarut total; HST: hari setelah transplanting & & & &
\end{tabular}

T: tinggi, S: sedang; PTT: padatan terlarut total; HST: hari setelah transplanting 
Seluruh karakter yang diamati dalam percobaan ini memiliki nilai duga heritabilitas arti luas yang tinggi, kecuali karakter panjang petiol yang memiliki nilai duga heritabilitas arti luas yang rendah. Karakter diameter buah memiliki nilai duga ragam genetik bernilai nol yang menyebabkan nilai duga heritabilitas arti luas karakter tersebut bernilai nol. Hal tersebut terjadi bukan karena tidak ada keragaman genetik, namun keragaman lingkungan pada karakter tersebut terlalu besar sehingga menutupi keragaman genetik. Karakter yang memiliki nilai duga ragam genetik yang tertutupi (bernilai negatif atau nol) tidak dapat dipelajari.

Nilai heritabilitas yang tinggi menunjukkan tingkat hubungan antara genotipe dan fenotipe yang tinggi. Nilai duga heritabilitas yang tinggi terjadi karena faktor genetik memiliki pengaruh yang lebih besar dari faktor lingkungan terhadap keragaan suatu karakter (Malik et al., 2006). Menurut Syukur et al. (2011), heritabilitas sangat bermanfaat dalam proses seleksi. Seleksi akan efektif jika populasi tersebut memiliki nilai duga heritabilitas yang tinggi sehingga seleksi dapat dilakukan pada generasi awal karena karakter dari suatu genotipe mudah diwariskan ke keturunannya. Sebaliknya jika nilai duga heritabilitas rendah maka seleksi baru dapat dilakukan pada generasi lanjut (Fehr, 1987).

\section{Analisis Tingkat Kesukaan}

Hasil uji Friedman menunjukkan perbedaan yang sangat nyata pada seluruh karakter dari genotipe yang diuji (Tabel 8). Tabel 8 juga menunjukkan tingkat kesukaan panelis terhadap empat karakter buah semangka yaitu warna daging buah, aroma daging buah, tekstur daging buah, dan rasa daging buah. Panelis memiliki kecenderungan menyukai warna daging buah dari genotipe Bengkulu 1, Bengkulu 2, dan Bengkulu 3 yaitu warna merah dengan intensitas warna yang tua. Preferensi konsumen terhadap warna daging buah akan menentukan tingkat permintaan pasar (Sobir dan Siregar, 2010).

Aroma daging buah yang secara relatif lebih disukai oleh panelis adalah hanya aroma dari genotipe Bengkulu 3. Aroma adalah reaksi dari senyawa kimia yang bersifat volatil, sehingga mudah mencapai sistem penciuman di bagian atas hidung dan memiliki konsentrasi yang cukup untuk dapat berinteraksi dengan satu atau lebih reseptor penciuman (Barcaloro et al., 1996).

Genotipe Kefaminano 3 dan Bengkulu 3 lebih disukai oleh panelis berdasarkan karakter tekstur daging buah. Berdasarkan Tabel 3 dan Tabel 6, panelis secara relatif lebih menyukai tekstur daging buah yang memiliki kekerasan $135.22 \mathrm{~mm} \mathrm{~s}^{-1}$ (Kefaminano 3) dan $131.83 \mathrm{~mm} \mathrm{~s}^{-1}$ (Bengkulu 3).

Rasa daging buah yang sangat disukai oleh panelis adalah daging buah dari genotipe Bengkulu 3 yang memiliki rata-rata padatan terlarut total sebesar 9.92 brix. Whitaker dan Davis (1962) menyatakan bahwa kualitas buah semangka sangat erat kaitannya dengan kandungan padatan terlarut total. Nilai padatan terlarut total menunjukkan tingkat kemanisan yang dikandung oleh daging buah semangka.

Menurut Sobir dan Siregar (2010), buah semangka yang memiliki tingkat kemanisan tinggi merupakan kritera konsumen dan sangat diinginkan oleh konsumen. Berdasarkan seluruh karakter yang diuji oleh panelis, genotipe Bengkulu 3 merupakan genotipe yang potensial untuk diterima oleh konsumen.

Tabel 8. Rekapitulasi hasil uji Friedman dan skala hedonik terhadap karakter dari genotipe semangka yang diujikan

\begin{tabular}{lllllllll}
\hline \multirow{2}{*}{ Genotipe } & \multicolumn{2}{c}{ Warna } & \multicolumn{2}{c}{ Aroma } & \multicolumn{2}{c}{ Tekstur } & \multicolumn{2}{c}{ Rasa } \\
\cline { 2 - 9 } & Skala & Skor & Skala & Skor & Skala & Skor & Skala & Skor \\
\hline Kefaminano 1 & KS & 1.85 & KS & 1.55 & KS & 1.85 & KS & 1.75 \\
Kefaminano 2 & KS & 1.65 & KS & 1.55 & KS & 1.65 & KS & 1.65 \\
Kefaminano 3 & KS & 2.65 & KS & 2.35 & S & 2.65 & KS & 2.20 \\
Kefaminano 4 & KS & 1.95 & KS & 1.90 & KS & 1.95 & KS & 1.75 \\
Bengkulu 1 & S & 1.40 & KS & 1.95 & TS & 1.40 & KS & 1.75 \\
Bengkulu 2 & S & 2.40 & KS & 2.35 & KS & 2.40 & KS & 2.20 \\
Bengkulu 3 & S & 3.20 & S & 3.00 & S & 3.20 & SS & 3.50 \\
Bengkulu 4 & KS & 2.45 & KS & 1.80 & KS & 2.45 & KS & 2.35 \\
Sugar Baby & KS & 2.20 & KS & 1.65 & KS & 2.20 & TS & 1.40 \\
Chi-Square & & $60.39^{* *}$ & & $60.64^{* *}$ & & $55.48^{* *}$ & & $84.82^{* *}$ \\
\hline
\end{tabular}

TS: tidak suka, KS: kurang suka, S: suka, SS: sangat suka; **berbeda nyata berdasarkan uji Friedman pada taraf $1 \%$ 


\section{Karakter Kualitatif}

Genotipe Bengkulu 1, Bengkulu 2, dan Bengkulu 3 memiliki warna hitam pada dasar testa, tidak memiliki warna sekunder testa, benih berukuran kecil, daun berwarna hijau dengan derajat cuping daun lemah (Tabel 9). Seluruh genotipe memiliki kulit buah berwarna hijau dengan intensitas yang bervariasi. Warna merah pada dasar testa dimiliki oleh genotipe Kefaminano 1 dan Kefaminano 2 sedangkan genotipe Kefaminano 3 dan Kefaminano 4 memiliki testa dengan warna dasar merah kecoklatan. Genotipe Bengkulu 4 memiliki testa dengan warna dasar krem dan warna dasar testa pada genotipe Sugar Baby adalah coklat.

Hanya genotipe Kefaminano 2, Kefaminano 3, Kefaminano 4, dan Sugar Baby yang memiliki warna sekunder testa pada penelitian ini. Benih berukuran kecil dimiliki oleh genotipe Kefaminano 2, Kefaminano 3, Bengkulu 1, Bengkulu 2, dan Bengkulu 3. Genotipe Kefaminano 1, Kefaminano 4, dan Bengkulu 4 memiliki benih dengan ukuran yang sangat kecil.

Tabel 9. Rekapitulasi hasil pengamatan karakter kualitatif benih, daun, dan kulit buah dari genotipe semangka yang diujikan

\begin{tabular}{lccccccc}
\hline Genotipe & WDT & WST & UB & WD & DCD & WKB & IWKB \\
\hline Kefaminano 1 & merah & tidak ada & sangat kecil & hijau & lemah & hijau & muda \\
Kefaminano 2 & merah & ada & kecil & hijau-abu & kuat & hijau & sangat tua \\
Kefaminano 3 & merah-coklat & ada & kecil & hijau-abu & sedang & hijau & sangat tua \\
Kefaminano 4 & merah-coklat & ada & sangat kecil & hijau & sedang & hijau & sangat muda \\
Bengkulu 1 & hitam & tidak ada & kecil & hijau & lemah & hijau & sangat tua \\
Bengkulu 2 & hitam & tidak ada & kecil & hijau & lemah & hijau & sedang \\
Bengkulu 3 & hitam & tidak ada & kecil & hijau & lemah & hijau & tua \\
Bengkulu 4 & krem & tidak ada & sangat kecil & hijau & sedang & hijau & muda \\
Sugar Baby & coklat & ada & sedang & hijau-abu & sedang & hijau & sangat tua \\
\hline
\end{tabular}

WDT: warna dasar testa; WST: warna sekunder testa; UB: ukuran benih; WD: warna daun; DCD: derajat cuping daun; WKB: warna kulit buah; IWKB: intensitas warna kulit buah

Benih dengan ukuran sedang hanya dimiliki oleh genotype Sugar Baby. Seluruh genotipe memiliki daun yang berwarna hijau kecuali genotipe Kefaminano 2, Kefaminano 3, dan Sugar Baby yang memiliki daun berwarna hijau keabuan. Seluruh genotipe Bengkulu memiliki derajat cuping daun yang lemah, kecuali genotipe Bengkulu 4. Genotipe Kefaminano memiliki derajat cuping daun yang beragam. Genotipe Sugar Baby memiliki derajat cuping daun lemah.

Warna merah pada daging buah dimiliki oleh seluruh genotipe, kecuali genotipe Kefaminano 2, Kefaminano 3, dan Kefaminano 4. Intensitas warna daging buah yang tergolong tua dimiliki oleh genotipe Bengkulu 1, Bengkulu 2, Bengkulu 3, dan Bengkulu 4. Genotipe Kefaminano 1, Kef aminano 4, dan Sugar Baby memiliki intensitas warna daging buah yang tergolong sedang. Intensitas muda pada warna daging buah dimiliki oleh genotipe Kefaminano 2 dan Kefaminano 3 (Tabel 10).

Mohr (1986) menyatakan bahwa semangka dengan warna daging merah dengan intensitas yang tergolong tua lebih disukai dibandingkan dengan semangka yang memiliki daging buah berwarna merah muda, walaupun sekarang semangka dengan daging buah berwarna kuning mulai disukai oleh konsumen.

Tabel 10. Rekapitulasi hasil pengamatan karakter kualitatif bentuk, garis, dan daging buah dari genotipe semangka yang diujikan

\begin{tabular}{lllllll}
\hline Genotipe & WDB & IWDB & GB & BBB & DPB & DA \\
\hline Kefaminano 1 & merah & sedang & ada & elip melebar & sedang & dangkal \\
Kefaminano 2 & merah muda & muda & tidak ada & elip melebar & dangkal & dangkal \\
Kefaminano 3 & merah muda & muda & tidak ada & elip melebar & sedang & sedang \\
Kefaminano 4 & merah muda & sedang & ada & bundar & sedang & dangkal \\
Bengkulu 1 & merah & tua & ada & elip & dangkal dangkal & dangkal \\
Bengkulu 2 & merah & tua & ada & bundar & dangkal \\
Bengkulu 3 & merah & tua & ada & elip & dangkal & sedang \\
Bengkulu 4 & merah & tua & ada & elip memanjang & dangkal dangkal \\
Sugar Baby & merah & sedang & tidak ada & bundar & dangkal dangkal \\
\hline
\end{tabular}

WDB: warna daging buah; IWDB: intensitas warna daging buah; GB: garis buah; BBB: bentuk bujur buah; DPB: depresi pangkal buah; DA: depresi apex 
Karakter garis buah tidak dimiliki oleh genotipe Kefaminano 2, Kefaminano 3, dan Sugar Baby. Bentuk buah dari genotipe Kefaminano 1, Kefaminano 2, dan Kefaminano 3 tergolong elip melebar pada posisi membujur. Bentuk bundar pada buah dengan posisi membujur dimiliki oleh genotipe Kefaminano 4, Bengkulu 2, dan Sugar Baby. Genotipe Bengkulu 1 dan Bengkulu 3 memiliki bentuk elip pada buah dengan posisi membujur. Bentuk elip memanjang hanya dimiliki oleh genotipe Bengkulu 4. Seluruh genotipe yang diujikan memiliki depresi dangkal pada pangkal buah kecuali genotipe Kefaminano 1, Kefaminano 3, dan Kefaminano 4. Depresi sedang pada apex hanya dimiliki oleh genotipe Kefaminano 3 dan Bengkulu 3.

\section{Analisis Gerombol}

Analisis gerombol, sebagai salah satu teknik analisis multivariat, mampu mengombinasikan karakter kuantitatif dan kualitatif untuk mengukur keanekaragaman morfologi sekaligus menganalisis seberapa dekat atau seberapa jauh kekerabatan di antara kultivar atau aksesi (Gichimu et al., 2009). Analisis gerombol bertujuan mengelompokkan data pengamatan di dalam beberapa kelas sehingga anggota di dalam satu kelas lebih homogen atau serupa dibandingkan dengan anggota di dalam kelas lain (Wahyuni, 1994).

Analisis gerombol dilakukan pada 9 genotipe uji dengan 25 peubah kualitatif dan 9 peubah kuantitatif. Perhitungan koefisien ketidakmiripan menggunakan metode Gower dan pengelompokkan menggunakan metode Ward dengan pembagian menjadi tiga kelompok kekerabatan (Gambar 2). Analisis gerombol berdasarkan karakter kuantitatif dan kualitatif mengelompokkan genotipe semangka yang diujikan menjadi 3 kelompok kekerabatan dengan koefisien ketidakmiripan sebesar $63 \%$.

Berdasarkan kelompok kekerabatan yang terdapat pada Gambar 2, maka terdapat 3 kelompok kekerabatan genotipe. Kelompok pertama terdiri atas 3 genotipe yaitu: Kefaminano 2, Kefaminano 3, dan Sugar Baby. Kelompok kedua terdiri atas 3 genotipe yaitu: Bengkulu 1, Bengkulu 3, dan Bengkulu 4. Kelompok ketiga terdiri atas 2 genotipe yaitu Kefaminano 1 dan Kefaminano 4. Gambar 2 menunjukkan bahwa genotipe-genotipe yang berasal dari daerah yang sama akan mengelompok pada kelompok kekerabatan yang sama. Sugar baby sebagai varietas komersil pembanding memiliki kekerabatan yang secara relatif cukup dekat dengan genotipe Kefaminano 2 dan Kefaminano 3 yang berasal dari daerah Nusa Tenggara Timur.

Pengelompokan genotype dengan menggunakan analisis gerombol diharapkan dapat membantu dalam pemilihan tetua persilangan. Persilangan antartetua yang memiliki latar belakang genetik yang jauh diharapkan akan menghasilkan keturunan silang tunggal yang memiliki nilai heterosis yang lebih tinggi dibanding tetua dengan latar belakang genetik dekat (Poehlman dan Sleeper, 1995).

Berdasarkan seluruh analisis diatas, heritabilitas arti luas pada seluruh karakter tergolong tinggi kecuali panjang petiol, maka seleksi berpotensi akan efektif. Jika kegiatan pemuliaan tanaman diarahkan untuk mendapatkan bobot buah yang tinggi, dapat menggunakan genotipe Bengkulu 2. Genotipe Bengkulu 3 dan Kefaminano 4 juga memiliki potensi untuk menghasilkan bobot buah yang tinggi karena memiliki korelasi positif yang sangat nyata dengan panjang dan diameter buah.

Kegiatan pemuliaan tanaman yang diarahkan untuk mendapatkan genotipe dengan perikarp yang tipis, dapat menggunakan genotipe Kefaminano 3 atau dapat juga menggunakan genotipe Bengkulu 1, Bengkulu 2, Bengkulu 4, dan Sugar Baby yang menunjukkan hasil tidak berbeda nyata pada uji DMRT $5 \%$.

Kegiatan pemuliaan tanaman terhadap karakter kekerasan daging buah dapat menggunakan genotype Bengkulu 3 dan Kefaminano 3 yang disukai oleh panelis dengan kisaran tingkat kekerasan sebesar 131.83-135.22 $\mathrm{mm} \mathrm{s}^{-1}$. Genotipe Kefaminano 3, Bengkulu 1, Bengkulu 2 dan Bengkulu 3 memiliki potensi untuk dikembangkan sebagai genotipe yang memiliki padatan terlarut total tinggi. Kegiatan pemuliaan tanaman ke arah waktu buah siap panen yang lebih singkat dapat menggunakan genotipe Kefaminano 1, Kefaminano 3, dan Bengkulu 2 yaitu selama \pm 86 HST.

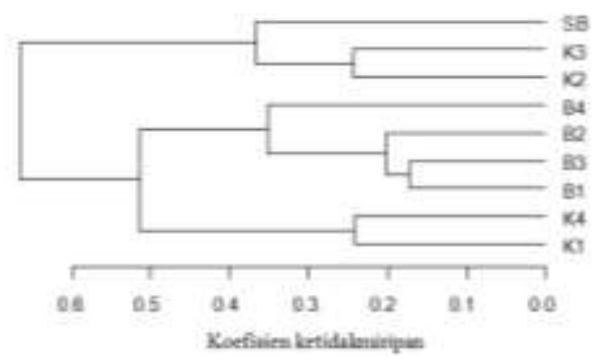

Gambar 2. Pengelompokan genotipe semangka berdasarkan karakter kualitatif dan kuantitatif 


\section{KESIMPULAN}

Genotipe semangka yang diuji menunjukkan keragaman karakter-karakter agronomi pada seluruh karakter yang diamati yaitu bobot buah, panjang buah, diameter buah, panjang petiol, kekerasan daging buah, tebal perikarp, padatan terlarut total daging buah, hari berbunga, dan hari panen. Seluruh karakter tersebut memiliki nilai duga heritabilitas arti luas yang tinggi kecuali karakter panjang petiol yang memiliki nilai duga heritabilitas arti luas sedang, sehingga seleksi efektif dilakukan pada karakter tersebut. Karakter bobot buah memiliki korelasi positif secara nyata pada taraf 5\% terhadap karakter panjang buah, diameter buah, dan tebal perikarp, serta berkorelasi negatif secara nyata terhadap karakter hari berbunga pada taraf 5\%. Analisis gerombol dengan metode Gower menunjukkan bahwa genotipe uji memiliki koefisien ketidakmiripan sebesar $63 \%$ dan genotipe yang berasal dari daerah yang sama masuk ke dalam kelompok kekerabatan yang sama. Berdasarkan hasil uji hedonik, hanya genotipe Bengkulu 3 yang disukai oleh panelis terhadap seluruh karakter yaitu rasa, aroma, tekstur dan warna daging buah.

\section{DAFTAR PUSTAKA}

Aditya, J.P., Bhartiya, P., Bhartiya, A. 2011. Genetic variability, heritability, and character association for yield and component characters in soybean $(G$. Max (L.) Merrill). J. Central Europ Agric. 12(1):27-34.

Allard, R.W. 1960. Principle of Plant Breeding. New York (US): John Wiley and Sons Inc.

Barcaloro, R., Tutta, C., Casson, P. 1996. Aroma compound. Di dalam: Handbook of Food Analysis. Volume ke-1. Nollet LML, editor. New York (US): Marcell Dekker Inc.

[BMKG] Badan Meteorologi Klimatologi dan Geofisika. 2015. Data Iklim Stasiun Dramaga. Bogor (ID): BMKG.

[BPS] Badan Pusat Statistik. 2014. Produksi sayuran di Indonesia [Internet]. [diunduh 30 September 2014]. Tersedia pada: http://www.bps.go.id

Cahyono, B. 1996. Budidaya Semangka Hibrida. Cetakan ke-1. Solo (ID): CV Aneka.
Eckebil, J.P., Ross, W.M., Gardner, C.O., Maranville, J.W. 1977. Heritability estimates, genetic correlations, and predicted gains from S1 progeny test in three grain sorghum random-mating populations. Crop Sci.17(3):373-377.

Falconer, D.S. 1964. Introduction to Quantitative Genetics. New York (US): The Ronald Press.

Fehr, W.R. 1987. Principles of Cultivar Development Volume I: Theory and Technique. New York (US): MacMilan Publishing Company.

Gichimu, B.M., Owuor, B.O., Mwai, G.N., Dida, M.M. 2009. Morphological characterization of some wild and cultivated watermelon (Citrullus $s p$.) accessions in Kenya. $J$ of Agricultural and Biological Science. 4(2):10-18.

Gupta, S.K., Verma, S.R. 2000. Variability, heritability, and genetic advance under normal and rainfed conditions in durum wheat (Triticum durum Desf). Indian J Agric Res. 34(2):122-125.

Jalata, Z., Ayana, A., Zeleke, H. 2011. Variability, heritability, and genetic advance for some yield and yield related traits in ethiopian barley (Hordeum vulgare L.) landraces and crosses. Int $J$ Plant Breeding and Genet. 5(1):44-52.

Kalie, M.B. 1993. Bertanam Semangka. Jakarta (ID): Penebar Swadaya.

Kusdiarti, L. 1986. Genetika Tumbuhan. Yogyakarta (ID): Gadjah Mada University Press.

Malik, M.F.A., Ashraf, M., Qureshi, S., Ghafoor, A. 2006. Utilization of diverse germplasm for soybean yield improvement. Asian J Plant Sci. 5(4):663-667

Mohr, H.C. 1986. Breeding Vegetable Crops: Watermelon breeding. Basset MJ, ed. Westport (US): AviPublishing Company Inc.

Poehlman, J.M, Sleeper DA. 1995. Breeding Field Crops. New Delhi (IN): The Avi Publishing Company Inc. 
Poespodarsono, S. 1988. Dasar-dasar Ilmu Pemuliaan Tanaman. Bogor (ID): Pusat Antar Universitas, Institut Pertanian Bogor.

Poste, L.M., Mackie, D.A., Butler G, Larmond E. 1991. Laboratory Methods for Sensory Analysis of Food. Ottawa (CA): Research Brand Agriculture Canada.

[PPVT] Pusat Perlindungan Varietas Tanaman. 2007. Panduan Pengujian Individual Kebaruan, Keunikan, Keseragaman, dan Kestabilan. Jakarta (ID): PPVT.

Prajnanta, F. 2003. Agribisnis Semangka Non Biji. Cetakan ke-5. Jakarta (ID): Penebar Swadaya. Rukmana R. 1994. Budidaya Semangka Hibrida. Yogyakarta (ID): Kanisius.

Saleem, U., Khaliq, I., Mahmood, T., Rafique, M. 2006. Phenotypic and genotypic correlation coefficients between yield and yield components in wheat. J Agric Res. 44(1).

Singh, R.K., Chaudary, B.D. 1979. Biometrical Methods in Quantitative Genetic Analysis. New Delhi (IN): Kalyani Publisher.
Sobir, Siregar, F.D. 2010. Budi Daya Semangka Panen 60 Hari. Depok (ID): Penebar Swadaya.

Stansfield, W.D. 1991. Schaum's Outline of Theory and Problems of Genetics. New York (US): The McGraw-Hill Companies.

Sunarjono, H.H. 2004. Prospek Berkebun Buah. Jakarta (ID): Penebar Swadaya.

Syukur, M., Sujiprihati, R., Yunianti, R., Kusumah, D.A. 2011. Pendugaan ragam genetik dan heritabilitas karakter komponen hasil beberapa genotipe cabai. J Agrivigor Ind. 10(2): 148-156.

Thormann, C.E., Ferreira, M.E., Camargo, L.E.A., Tivang, J.G., Osborn, T.C. 1994. Comparison of RFLP and RAPD markers to estimating genetic relationship within and among cruciferous species. Theor Appl Genet 88(8): 973-980.

Wahyuni, S. 1994. Analisis genetik karakter kuantitatif dan pecah buah pada tanaman tomat (Lycopersicum esculentum Mill). [tesis]. Bogor (ID): Institut Pertanian Bogor.

Whitaker, T.W., Davis, GN. 1962. Cucurbits. London (UK): Leonard Hill (Books) Ltd. 